\title{
Influence of use of Activinspire interactive whiteboards in classroom on students' learning
}

\author{
Jolita Dudaitè \\ jolitad@mruni.eu \\ Mykolas Romeris University, Lithuania \\ Romas Prakapas \\ prakapas@mruni.eu \\ Mykolas Romeris University, Lithuania
}

\begin{abstract}
With the changing students' generations and education content as well as modernization of educational technologies, various technical solutions are increasingly used by the teachers to supplement daily classroom activities. One of the novelties introduced in Lithuania in 2013 - ActivInspire system - was oriented towards mathematics and science education process in the $5^{\text {th }}$ classes. The purpose of the survey presented in this article is to summarize one school year's teaching experience of teachers in organising educational activity in classroom by using interactive teaching tools (ActivInspire system) in terms of assessing influence of technologies on students' learning.

Teachers using ActivInspire interactive whiteboard for teaching mathematics and science in the $5^{\text {th }}$ classes participated in the survey. The survey method - qualitative. During one school year, the teachers were writing reflections about their experience in using interactive learning tools in classroom: interactive whiteboard, electronic textbooks and audience response system.

When speaking about the influence of use of Activinspire on students, the teachers mostly emphasize that students like working with interactive teaching tools or find such activity interesting and appealing. The teachers also remark that these tools encourage the students to be more active; they are convenient as well as effective in the learning process, encourage the students to learn more and have influence on their study results. The negative aspects mentioned by the teachers were such that it is difficult for the students to maintain discipline; students' interest and enthusiasm in using the interactive tools slackens over the school year; technical problems sometimes occur.
\end{abstract}

\section{Keywords}

ActivInspire; interactive whiteboard; general education school; information and communication technologies 


\section{Introduction}

Penetration of new educational technologies into today's educational process became natural. More and more specialists discuss the new requirements for the students. The World Economic Forum report New Vision for Education (2016) marks the increasing gap between skills which are educated at schools and those actually needed for each young person and adult later in real life. Analysis of four competencies and six necessary skills marked in the said report clearly shows that the days when a teacher acts as a guardian and conveyor of final truths and the teaching is implemented by teacher speaking and learning - by students listening must come to an end. With the penetration of new technologies and the Internet into daily life, new generation era starts (McCrindle \& Wolfinger, 2010). New learning paradigm based on learning principle raises new requirements for a teacher: ability to work in various school environments, dissemination of new ideas, assessment of knowledge and achievement, need of information literacy, search for new teaching methods (Laužackas, et al., 2008). In response to the role of new technologies in education, representatives of science and business try to develop and offer various solutions (e.g. Interactive Classroom; ActivInspire; Classroom of the Future, etc.) and establish specialized research centres (e.g. Center for Educational Technologies, etc.). The studies carried out (Buil, et al., 2016) show that application of technologies in study process is primarily associated with increased motivation of students. The new technologies encourage and wake the students, and turn the process of learning into a playful activity. In addition to raising initial interest and extrinsic stimulation, information and communication technologies also create certain students' intercommunication field (Barth-Cohen, et al., 2016) which is characteristic of the new generation students.

Children and young people studying is such environment, called "digital natives" by some scientists (McCarrick \& Xiaoming, 2007), do not wish to have only traditional routine chalkboard lessons all the time or study by reading only the texts printed in textbooks. Such students need visual representation and various technological interactions; therefore, teaching and learning process is gradually becoming hardly conceivable without management and proper application of the latest technologies.

M. Prensky (2009) provides the terms of "digital natives" and "digital immigrants" used in public space, especially in English speaking one. The former covers those who grew up with digital technologies and these technologies became an integral part of their perception of the world. The digital generation knows well how to use online resources and technologies as well as new software, to communicate in social networks, to blog. Digital immigrants, as a contrast to digital natives, refer to those who can learn how to use the latest technologies yet it requires much more effort and time as compared to digital natives (Zevenbergen, 2007). Teachers are like the immigrants of the digital world.

Problem raised in the article - experience of the teachers in using the latest technologies (ActivInspire system) in the educational process; what influence of these technologies on students' learning do the teachers see?

Subject - one school year's teaching experience of teachers using ActivInspire interactive whiteboard for teaching mathematics and science in the $5^{\text {th }}$ classes.

Purpose is to summarize one school year's teaching experience of teachers in working with interactive teaching tools (ActivInspire system) in terms of assessing influence of technologies on students' learning. 
Organisation and methods of the survey. The survey was prepared based on the case study strategy (Yin, 2014) with the aim to summarize the experience of a specific region - Lithuania - in introducing new educational technologies in the educational process. The implementation of the survey began in 2013-2014 school year; teachers using ActivInspire interactive whiteboard for teaching mathematics and science in the $5^{\text {th }}$ classes participated in the survey. Various methods of compilation and analysis of the survey data were used: literature analysis, content analysis, and structure trees. Data compilation instrument - teachers' reflections about their work experience in using interactive teaching tools. QDA Miner4 and Excel programmes were used for carrying out the categorization, Visio programme - for drawing subcategories trees.

Research ethics - the survey was carried out following the main principles of research ethics (Valerio \& Mainieri, 2008; Mertens \& Ginsberg, 2009; Herrera, 2010). All participants of the survey participated in the survey on a voluntary basis. The survey purpose, potential risks, participants' rights (e.g. possibility to stop participation in the survey) were explained to the survey participants; their consent was received. During the survey, confidentiality principle was met; the reflections provided by the survey participants were used by the researchers only. The survey material is provided only in a summarized way and in such a manner that the survey report would not reveal the identity of the survey participants thus ensuring their confidentiality. After the survey, the summarized survey material was provided to the survey participants.

\section{ActivInspire system in schools of Lithuania}

Since the restoration of the independence in 1990, the education in Lithuania has been gradually moving from the education based on teaching paradigm to that based on learning paradigm. The entire educational content was changed in several stages, and other main changes in that respect took place (Prakapas, 2010). As already mentioned, awareness of and ability to use the interactive learning strategies is not enough for today's teacher (Buehl, 2004); the new technologies are gradually entrenching in classrooms. If a decade ago computers and interactive whiteboards could be rarely seen in the training premises (not ICT classrooms), today students are not easily surprised by such tools. Students usually have quite extensive experience in using digital technologies.

By summarizing the peer reviews, V. Targamadzè (2010) states that the existing problems related with unsuccessful change in teaching and learning paradigms provided at the beginning of the education reform is associated with teachers' unwillingness to work in a new manner and students' unwillingness to learn. Many studies are carried out by education specialists when dealing with problems related with students' learning motivation. Both classic pedagogical works and the latest scientific and methodological publications often note that the selection of proper pedagogical measures is important for enhancing students' learning motivation and maintaining it during the studies. One of Lithuania's major publishing houses Šviesa which is engaged in publishing of educational literature, in cooperation with Alma Litera Sprendimai, the Education Development Centre and Mykolas Romeris University (MRU) estimated technological environment of schools in Lithuania and offered the schools a product of internationally recognised Promethean company ActivInspire (Aktyviosios klasès sprendimas, 2016). It is noteworthy that this product is not just "transferred" from English speaking environment to Lithuanian - Lithuania's general education schools were offered a product with "active content". 
According to Juškienè (2011), interactive system solutions of Promethean are technical tools for bringing the educational process to higher level, applying traditional educational methods in a modern way, providing lesson in an interesting manner by immediately using the newest technologies, student active participation and audience response system, the Internet, video material and sound on an interactive whiteboard. ActivInspire is all-in-one system: interactivity, cooperation, multimedia technologies experience developed to involve all students in the learning process and excite their imagination - to create usual digital environment for students (Juškiene, 2011 , p. 3). All this is particularly important in order to individualize the learning process. The data of study carried out by D. Gedminienès and A. Gumuliauskienès (2008) show that lack of sufficiently targeted organisation of the teaching process and optimal pace in classroom hinders achievement of education quality because thus not all students manage to master the educational material so quickly.

Use of ActivInspire system together with material specially adjusted to the system:

- helps to integrate digital technologies into educational process;

- expands the digital demonstration and modelling opportunities;

- improves communication between teachers and students in the classroom;

- reduces time spent by the teachers for preparation for lessons;

- increases learning speed and depth;

- expands the range of didactic methods of the teacher (Juškienè, 2011; Aktyviosios klasès sprendimas, 2016).

It should be noted that based on the data of the first quantitative survey in Lithuania (Lamanauskas, et al., 2012) the features indicated by the software producers correlate with the teachers' assessment and experience in using ActivInspire system in daily pedagogical activity.

\section{Survey methodology}

Organisation of the survey. The survey was carried out in the 2013-2014 school year. Teachers who use ActivInspire interactive whiteboard for teaching mathematics and science in the $5^{\text {th }}$ classes participated in the survey. The survey method - qualitative. During a school year, the teachers were writing reflections about their experience in using the interactive teaching tools in classroom: interactive whiteboard, electronic textbooks and audience response system. Electronic textbooks for mathematics and science lessons in the $5^{\text {th }}$ class were prepared by publishing house Šviesa. The reflections were written from September to May inclusive (except January and February), once a week, in free format describing experience in working with the interactive teaching tools.

Data analysis methods and tools. Content analysis method was used for the analysis of teachers' reflections by distinguishing hierarchical categories and subcategories and drawing category trees. QDA Miner4 and Excel programmes were used for carrying out the categorization, Visio programme - for drawing subcategories' hierarchical trees.

Survey sample. Texts of reflections of 3 teachers of mathematics and 3 teachers of science written over the school year (2013-2014) were used for survey analysis. At the beginning of school year, 20 teachers were selected for the survey, yet only 6 of them were writing reflections until the end of the school year (the rest of the teachers stopped writing reflections during the school year). 
Teachers working in different types of school in cities and towns were selected for the survey. The participants of the survey actively used interactive teaching tools in one of the $5^{\text {th }}$ classes; they wrote reflections in connection with that class.

\section{Survey results and discussion}

Analysis of reflections material showed that teachers' impressions on the use of interactive teaching tools in classroom can be grouped into several groups: impressions related with teachers (their status, preparation to use interactive teaching tools, etc.), impressions related with students (differences in their participation in lesson when interactive teaching tools are used) and impressions related with organisation of lesson (its structure, management of class and time, etc.). Teachers' assessment of use of the ActivInspire interactive whiteboard in classroom in terms of organisation of lesson and a teacher are provided in other publications (Dudaitè \& Prakapas, 2016a, 2016b) so this article presents only the survey results related with influence of use of interactive teaching tools in classroom on students.

The survey participants' reflections material on the things they relate with student experience when interactive teaching tools are used in lessons was analysed, and the received category/subcategory trees are provided in Fig. 1 and Fig. 2. 


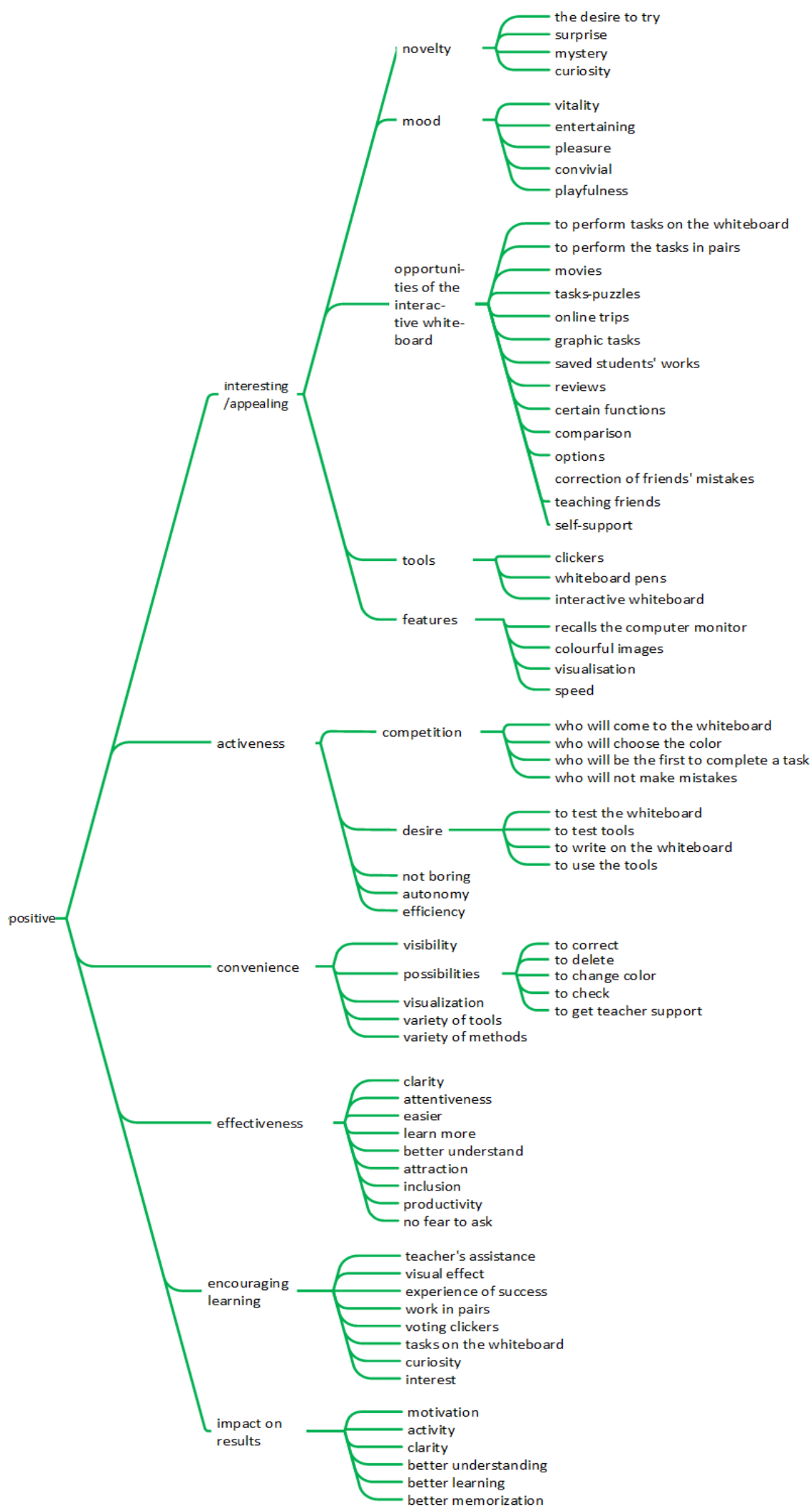

Figure. 1. Category tree: positive influence of application of interactive teaching tools on students' learning. 
Fig. 1 shows that the participants of the survey, in principle, mostly use positive descriptions to describe the influence of use of interactive teaching tools on students. Experience described as positive can be grouped into six large categories: interesting/appealing, activeness, convenience, effectiveness, encouraging learning and impact on results.

It was mostly emphasized that students like working with the interactive teaching tools in lessons or find such activity interesting. Students like novelty - they are curious and wish to try new things; the interactive whiteboard and clickers seem mysterious and unexpected to them. Students find lessons with interactive tools interesting and appealing because such lessons are entertaining, pleasant and convivial and they remind of a game. During such lessons students willingly perform the tasks - the lesson is lively.

The students particularly like the opportunities provided by the interactive whiteboard: they willingly go to the whiteboard to do the tasks and particularly like to perform the tasks in pairs; the students whose work is saved and later reviewed are especially content because they feel important and proud. The students like the movies, playful tasks-puzzles presented in an interesting way, online trips, great amount of graphic tasks, certain functions (e.g. tasks where whiteboard function - "container" - could be used), option to select colours and font size, possibility to see their and other students' evaluation, to compare their own solutions with the ones provided, to teach others, to notice and correct the mistakes of friends, to demonstrate how they manage the tools. As regards the tools, the students' favourites are clickers, whiteboard pen and, definitely, whiteboard. Working with interactive whiteboard is much more interesting for the students because the view is displayed as if in the computer monitor, images are colourful, presentations are visually attractive and everything happens quickly.

The use of the interactive teaching tools encourages the students to be active. They compete with one another for the opportunity to come to the whiteboard, to be the first to complete a task, make no mistakes, even for the opportunity to select colour. The students are eager to try the most interesting whiteboard, write on it with the pen and perform other work; everyone wants to try and demonstrate how they can use callipers, protractor and other drafting instruments. Such lessons are not boring for the students, vice versa - they are productive as the students can work both on their own and together with class.

In addition to all positive aspects, the interactive teaching tools are also convenient for students: very good visibility even for those who have sight problems or sit far from the board, use of visual methods, variety of methods and tools. It is very convenient because it allows correcting, erasing, changing colours, checking your own solutions with those provided on the board, receiving teacher's assistance even without asking because the teacher sees who needs help and can provide it in a timely manner.

The interactive tools are effective for students. They help to focus attention, perform work more easily; the students learn more and better understand; with the interactive whiteboard everything is clear or at least clearer for the students than without it. Such lessons attract and encourage students to work, they are not afraid to ask questions, almost all students participate in the activity, lessons are productive because there is no possibility to "oversleep" the lesson.

Success, curiosity, timely assistance of a teacher, visual effect and interest encourage learning. Performance of the tasks on the whiteboard, use of clickers and even work in pairs also contributes considerably to that. 
All this motivates the students and has decisive influence on their study results. Students' activity, clarity, as well as better understanding, memorization and learning definitely improve their results.

When speaking about influence of application of the interactive teaching tools on students, some negative aspects were also mentioned by the teachers (Fig. 2). The negative experience indicated by the teachers can be grouped into four large categories: discipline, change in mood, limitations, technical difficulties.

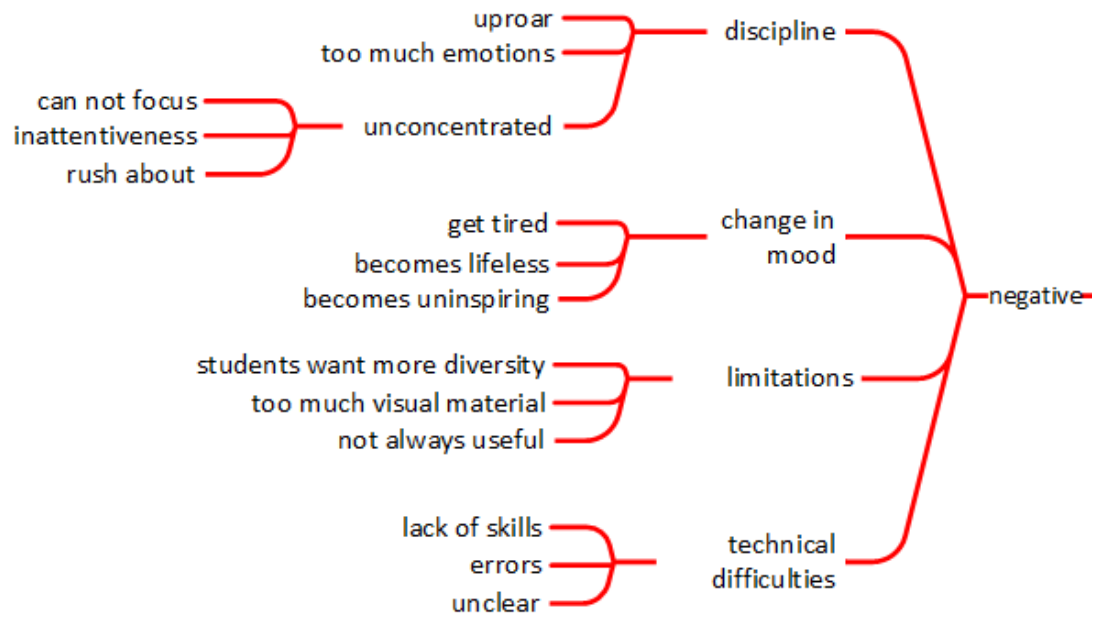

Figure. 2. Category tree: negative influence of application of interactive teaching tools on students' learning.

Very important point for the teachers is that application of interactive tools makes it hard for the students to maintain discipline - the students go through too much emotions when they fail to use the interactive tools, there is an uproar in the classroom; the students who are waiting to be invited to the interactive whiteboard cannot concentrate, are inattentive and cannot focus on their individual work.

The teachers notice the change in students' mood over the time in respect of the interactive teaching tools - they get tired of the interactive whiteboard; their interest in new technological methods begins to slacken at the end of the school year; the interactive experiments become lifeless and uninspiring, there is a wish for real experiments rather than interactive ones.

The teachers also indicate the limitations of the interactive whiteboard: presentation of excessive visual material is not always useful as not all students conceive the essence of the topic; sometimes students lack competence to use the whiteboard; students want to use not only the interactive whiteboard but also traditional blackboard which they miss.

There are sometimes technical difficulties which are mostly related with lack of skills to work with interactive tools - although today's students have rather good command of information and communication technologies yet it still happens that some students do not always know how to use them properly. 


\section{Conclusions}

The participants of the survey, in principle, mostly use positive descriptions to describe the influence of use of interactive teaching tools on students. It was mostly emphasized that students like working with the interactive teaching tools in lessons or find such activity interesting and appealing. The teachers also mention that these tools encourage the students to be active, they are convenient, effective in the learning process, encourage the students to learn more and have influence on their study results.

In addition to the positive experience, the teachers also mention several negative aspects: it is difficult for the students to maintain discipline; students' interest and enthusiasm in using the interactive tools slackens over the school year; technical problems sometimes occur.

\section{References}

Aktyviosios klasės sprendimas (2016). Retrieved from: http://www.aktyviklase.lt/aktyviosios-klasessprendimas/iranga/activinspire-programine-iranga/

Barth-Cohen, L., Smith, M., Capps, D., Lewin, J., Shemwell, J., \& Stetzer, M. (2016). What are Middle School Students Talking About During Clicker Questions? Characterizing Small-Group Conversations Mediated by Classroom Response Systems. Journal of Science Education \& Technology, 25(1), 50-61.

Buehl, D. (2004). Interaktyviojo mokymosi strategijos. Vilnius: Garnelis.

Buil, I., Catalán, S., \& Martínez, E. (2016). Do clickers enhance learning? A control-value theory approach. Computers \& Education, 103, 170-182.

Dudaitè, J., \& Prakapas, R. (2016a). Lietuvos mokytoju, dirbančiu su „ActivInspire" interaktyviaja sistema. Social Work, 14(1), 82-91.

Dudaitè, J., \& Prakapas, R. (2016b). Lietuvos mokytoju, dirbančiu su „ActivInspire" interaktyviaja sistema, patirtys organizuojant pamokos darba. Social Work, 14(2), 199-209.

Gedminienè, D., \& Gumuliauskienè, A. (2008). Ugdymo kokybės vertinimas bendrojo lavinimo mokykloje: mokytoju ir mokiniu požiūris. Acta Paedagogica Vilnensia, 21, 75-88.

Herrera, C. (2010). Ethics in the Research Process. In Neil J. Salkind (Ed.), Encyclopedia of Research Design. (pp. 426-431). Thousand Oaks, CA: SAGE Publications, Inc.

Yin, R. K. (2014). Case study research: design and methods. Los Angeless (Calif.): Sage Publications.

Juškienè, Z. (2011). Interaktyviu technologiju naudojimas ActiveInspire aplinkoje. Vilnius: UAB „Konferenciju ir audiovizualinès sistemos".

Lamanauskas, V. et. al. (2012). Aktyviosios klasès sprendimas: tyrimo ataskaita. Šiauliai: „Scientia Educologica".

Laužackas, R., Gedvilienè, G., Tūtlys, V., \& Juozaitienè, D. (2008). Mokytoju kvalifikacijos tobulinimo poreikiai. Pedagogika, 89, 29-44.

McCarrick, K., \& Xiaoming, L. (2007). Buried Treasure: The Impact of Computer Use on Young Children's Social, Cognitive, Language Development and Motivation. AACE Journal, 15(1), 73-95.

McCrindle, M., \& Wolfinger, E. (2010). Generations Defined. Ethos, 18(1), 8-13.

Mertens, D. M., \& Ginsberg, P. E. (2009). The handbook of social research ethics. Thousand Oaks, CA: SAGE Publications, Inc. 
New Vision for Education: Fostering Social and Emotional Learning Through Technology (2016). Retrieved from: http://www3.weforum.org/docs/WEF_New_Vision_for_Education.pdf

Prakapas, R. (2010). Švietimas ir ugdymas Lietuvoje: sistemos ir ideju kaita. Regnum est: 1990 m. kovo 11osios nepriklausomybès Aktui - 20: Liber Amicorum Vytautui Landsbergiui (p. 791-807). Vilnius: Mykolo Romerio universiteto Leidybos centras.

Prensky, M. (2009). H. Sapiens Digital: From Digital Immigrants and Digital Natives to Digital Wisdom. Innovate: Journal Of Online Education, 5(3).

Targamadzè, V. (2010). Ugdymo ir ugdymosi paradigma bendrojo lavinimo mokykloje: realija ar vizija? Acta Paedagogica Vilnensia, 24, 69-77.

Valerio, M., \& Mainieri, T. (2008). Ethical Principles. In Paul J. Lavrakas (Ed.), Encyclopedia of Survey Research Methods. (pp. 244-247). Thousand Oaks, CA: Sage Publications, Inc.

Zevenbergen, R. (2007). Digital Natives Come to Preschool: Implications for Early Childhood Practice. Contemporary Issues In Early Childhood, 8(1), 19-29. 